\title{
Calcium excretion, apparent calcium absorption and calcium balance in young and elderly subjects: influence of protein intake
}

\author{
BY DAPHNE L. E. PANNEMANS ${ }^{1}$, GERTJAN SCHAAFSMA ${ }^{2}$ \\ AND KLAAS R. WESTERTERP ${ }^{1}$ \\ 'Department of Human Biology, University of Limburg, PO Box 616, 6200 MD Maastricht, \\ The Netherlands \\ ${ }^{2}$ Department of Human Nutrition, TNO Toxicology and Nutrition Institute, PO Box 360, 3700 MD Zeist, \\ The Netherlands
}

(Received 14 June 1996 - Revised 23 August 1996 - Accepted 19 September 1996)

\begin{abstract}
The present study was conducted to investigate the effect of dietary protein on urinary Ca excretion, apparent $\mathrm{Ca}$ absorption and $\mathrm{Ca}$ balance in young and elderly subjects. Young adults $(n$ 29) and elderly persons ( $n$ 26) consumed diets containing $12 \%$ (diet A) and $21 \%$ (diet B) of total energy as protein for 3 weeks according to a randomized crossover design. Results showed no differences between the two age groups with respect to the interaction between protein intake and Ca excretion (both in urine and in faeces), apparent $\mathrm{Ca}$ absorption and $\mathrm{Ca}$ balance. Therefore analyses were done for both age groups separately and also for the whole group. In elderly persons and in the whole group the $\mathrm{Ca}$ excretion in faeces (as a percentage of $\mathrm{Ca}$ intake) was lower during the higher protein intake (elderly: $\operatorname{diet} \mathrm{A}, 106$ (SEM 7) \%; diet $\mathrm{B}, 86$ (SEM 7) \%; $P=0.018$; whole group: diet $\mathrm{A}, 99$ (SEM 4) \%; diet $B, 84$ (SEM 4) \%; $P=0.003$ ). In young adults faecal $C a$ excretion tended to be lower when they consumed diet B (diet A: 94 (SEM 5)\%; diet B: 83 (SEM 6)\%; $P=0.093$ ). Relative urinary Ca excretion was greater during the higher protein intake in young adults and in the whole group while relative urinary $\mathrm{Ca}$ excretion was not different in the elderly (diet A: 15 (SEM 1) \%, 14 (SEM 1) \%, 15 (SEM 1) \%; diet B: 16 (SEM 1) \%, 16 (SEM 1) \%, 17 (SEM 2) \% for the whole group, the young and elderly subjects respectively, $P=0.019 ; P=0.016 ; P=0.243)$. The resulting Ca balance was not influenced by the amount of protein in the diet in young adults. Values for the elderly and for the whole group showed that the $\mathrm{Ca}$ balance during diet $\mathrm{A}$ was significantly more negative compared with $\mathrm{Ca}$ balance during diet $\mathrm{B}$, despite the higher urinary $\mathrm{Ca}$ excretion during diet $\mathrm{B}$. It can be concluded that increasing the protein intake from 12 to $21 \%$ of total energy intake had no negative effect on Ca balance.
\end{abstract}

Calcium: Protein intake: Elderly

Several investigators have reported an increased urinary $\mathrm{Ca}$ loss when dietary protein is increased, sometimes leading to a negative Ca balance (Johnson et al. 1970; Walker \& Linkswiler, 1972; Anand \& Linkswiler, 1974; Allen et al. 1979; Schuette et al. 1980; Hegsted et al. 1981). The calciuretic effect of protein is attributable to an increased glomerular filtration rate and filtered $\mathrm{Ca}$ load and to a decreased tubular $\mathrm{Ca}$ reabsorption caused by sulfate that originates from S-containing amino acids (Kim \& Linkswiler, 1979; Schuette et al. 1980). Dietary P on the other hand reduces the urinary excretion of $\mathrm{Ca}$ by increasing the renal tubular reabsorption and counteracts, at least in part, the calciuretic action of protein. $\mathrm{P}$ has been shown to decrease urinary $\mathrm{Ca}$ regardless of $\mathrm{Ca}$ intake (Spencer et al. 1978a). Spencer et al. (1988) have put forward the suggestion that commonly used 
complex proteins, which contain $\mathrm{P}$, do not cause Ca loss. The same group described the effect of a high protein (meat) intake on $\mathrm{Ca}$ excretion, absorption and retention in male patients (age: 30-67 years) and concluded that a high protein intake, given as meat (complex proteins) does not lead to hypercalciuria and does not induce Ca loss (Spencer $e t$ $a l .1978 b, 1983$ ). Although this may be valid for young healthy adults it may not be so in healthy elderly people, who are already confronted with a negative Ca balance (Heany, 1986). Since a higher protein intake is probably preferable for the elderly (Pannemans et al. 1995 ) it is necessary to investigate the effect of a higher protein intake on Ca metabolism. It was the aim of the present study to investigate the effect of dietary protein on urinary $\mathrm{Ca}$ excretion, apparent $\mathrm{Ca}$ absorption and $\mathrm{Ca}$ balance in young and elderly subjects.

\section{MATERIALS AND METHODS}

\section{Subjects}

Subjects were twenty-nine young adults and twenty-eight elderly persons. They were recruited by advertisements in the local media. Elderly subjects were also recruited through contacts with alliances for the elderly. Mean age, height, weight and BMI are presented in Table 1. Two elderly women did not complete the whole study and they were excluded from this analysis. All subjects were certified to be in good health by a staff physician and gave informed consent to participate in the study after the procedures were explained to them. The protocol was approved by the university ethics committee.

\section{Protocol}

Subjects consumed two isoenergetic diets, for 3 weeks each, in a crossover design with a 'wash-out' period of at least 3 weeks. Diets contained 12 and 42 (diet A), and 21 and 33 (diet B) \% total energy intake from protein and fat respectively. During the experiment subjects were given both diets according to their estimated energy intake in random order. All meals and drinks were served daily at home, and subjects were not allowed to eat or drink anything else except for water, tea and coffee. They were asked to keep the coffee and tea consumption constant during the intervention study. The first week was a correction period in which energy intake could be adjusted if necessary. Compliance was not checked with a marker; however subjects were asked every day to eat everything provided, and to write down the foods they did not eat (if any), and everything they ate which was not

Table 1. Physical characteristics of the subjects

(Mean values with their standard errors)

\begin{tabular}{|c|c|c|c|c|c|c|c|c|}
\hline & \multicolumn{4}{|c|}{ Young subjects } & \multicolumn{4}{|c|}{ Elderly subjects } \\
\hline & \multicolumn{2}{|c|}{ Men } & \multicolumn{2}{|c|}{ Women } & \multicolumn{2}{|c|}{ Men } & \multicolumn{2}{|c|}{ Women } \\
\hline & Mean & $\mathrm{SE}$ & Mean & SE & Mean & SE & Mean & SE \\
\hline$n$ & \multicolumn{2}{|c|}{19} & \multicolumn{2}{|c|}{10} & \multicolumn{2}{|c|}{17} & \multicolumn{2}{|c|}{9} \\
\hline Age (years) & $30 \cdot 4 * * *$ & 1.2 & $27 \cdot 2 * * *$ & $1 \cdot 2$ & 71.6 & 1.2 & $67 \cdot 3$ & 1.5 \\
\hline Height (m) & $1.81 * * *$ & 0.01 & $1.68 *$ & 0.02 & 1.72 & 0.02 & 1.61 & 0.03 \\
\hline Weight (kg) & $76 \cdot 3$ & $2 \cdot 0$ & 60.8 & 2.4 & 73.8 & $3 \cdot 0$ & $68 \cdot 3$ & 3.0 \\
\hline BMI $\left(\mathrm{kg} / \mathrm{m}^{2}\right)$ & $23 \cdot 2^{*}$ & 0.4 & $21 \cdot 5^{* * *}$ & 0.6 & 24.9 & 0.8 & 26.5 & 1.1 \\
\hline
\end{tabular}

Mean values were significantly different from those for the corresponding elderly group: ${ }^{*} P<0.05, * * * P<0.001$. 
provided by the study. If necessary, corrections for nutrient intake were make. Furthermore it can be stated that subjects were very motivated to participate in the study and aware of the importance of compliance.

\section{Nutrition intervention}

For the purpose of the study fixed energy groups were defined $(7.5 ; 8.25 ; 9.00 ; \ldots$ up to $15.0 \mathrm{MJ} / \mathrm{d}$ ). The subjects were placed in the best fitting energy group according to their estimated energy intake as measured with a dietary record or with a dietary questionnaire (Pannemans \& Westerterp, 1993). During the nutrition intervention period the subjects were given a diet in pre-weighed portions; all leftovers were collected and weighed. Diets contained: wheaten bread plus diet margarine (Becel, Rotterdam, The Netherlands), marmalade (Hero, Breda, The Netherlands) and meat (sausage or smoked beef); potatoes plus vegetables (cabbage, beans), minced meat and gravy (Knorr, Hilversum, The Netherlands); yoghurt (Campina, Tilburg, The Netherlands), sugar, fruit cocktail (Zwaardemaker, Maarssen, The Netherlands), orange juice (Hero), milk (Campina) and cake (Jamin, Oosterhout, The Netherlands). The higher protein content of diet B was reached by an isoenergetic exchange between protein and fat. The isoenergetic exchange was achieved by using low-fat milk, low-fat yoghurt, low-fat gravy, bread and meat enriched with protein (sodium caseinate (DMV Campina Veghel) in dairy products, gluten (Excelsior, Latenstein Zetmeel B. V., The Netherlands) in bread, and soyabean (Protein Technology Institute, Iepen, Belgium) in minced meat) and by replacing sausage by smoked beef in diet B. Subjects were not allowed to use supplements. Diets were formulated to contain equal amounts of $\mathrm{Ca}$ and $\mathrm{P}$. We asked subjects to keep the $\mathrm{Na}$ intake the same during both experimental periods, since subjects acted as their own controls.

\section{Calcium excretion}

Samples of total diet, given during the intervention period, were collected and analysed for $\mathrm{Ca}$, energy, $\mathrm{N}$ and $\mathrm{P}$. Subjects collected total faeces for $3 \mathrm{~d}$ and total urine for $2 \mathrm{~d}$ at the end of each third week of the intervention period. Daily faeces collection started at 07.00 hours and continued until 07.00 hours the next day. Urine collection $(24 \mathrm{~h})$ started with the second voiding in the morning and included the first voiding of the next day. Faeces were collected for $3 \mathrm{~d}$ because this was the maximum compliance period for these elderly subjects.

After total weight and total volume of faeces and urine were measured, faeces and whole meals were homogenized and samples were freeze-dried. Dried samples were ashed at $600^{\circ}$ in a muffle furnace for $16 \mathrm{~h}$. The white ash was taken up in $0.1 \mathrm{M}-\mathrm{HCl}$ solution for measurement of $\mathrm{Ca}$ and $\mathrm{P}$ as indicated below. $\mathrm{Ca}$ in urine and in ashed samples of faeces and total diets was measured according to the method of Grindler \& King (1972) by complexometry with $o$-cresolphthalein as the complexone in a Hitachi 911 analyser (Boehringer, Mannheim, Germany) using Boehringer reagent no. 1125621. Inorganic phosphate was measured according to the method of Henry et al. (1974) by photospectrometry also in the Hitachi 911 analyser with a molybdate method using Boehringer reagent no. 104898 . The analytical methods were calibrated using two different sera for quality control (Boehringer Mannheim) and one human pooled quality control serum sample.

$\mathrm{Ca}$ balance was calculated as $\mathrm{Ca}$ intake minus $\mathrm{Ca}$ in faeces and urine. Energy content of the diets was measured by means of bomb calorimetry (Janke \& Kunkel, IKA Kalorimeter C-400, Staufen im Breisgau, Germany) (Pannemans \& Westerterp, 1993), 
dietary $\mathrm{N}$ content was measured with a Heraeus analyser (type CHN-O-rapid; Hanau, Germany) (Pannemans et al. 1995). Urinary creatinine concentrations were measured to check the completeness of the $24 \mathrm{~h}$ urine collection.

\section{Statistics}

Values are expressed as means with their standard errors. ANOVA was performed on all data using three-way ANOVA for repeated measures with sex (male/female) and age (young adults/elderly) as the between-group factors and diet as the within-subject factor. A probability level $<0.05$ was considered statistically significant. Since sex appeared to have no influence on the outcome of the data, differences between measurements and age groups were analysed using two-way ANOVA for repeated measures with age (young adults/ elderly) as the between-group factor and diet as the within-subject factor. Regression analysis was used to assess associations between measured variables.

\section{RESULTS}

\section{Diets}

Table 2 shows the nutrient intake during the experimental diet periods. Energy intake was the same during diet $\mathrm{A}$ and diet $\mathrm{B}$ for both age groups. $\mathrm{N}$ intake was, as planned, significantly higher during diet $B$. $N$ intake increased by $73 \%$ and $79 \%$ respectively for the elderly and the young subjects. Although diets were formulated to contain equal amounts of $\mathrm{Ca}$ and $\mathrm{P}$, the analysed $\mathrm{Ca}$ and $\mathrm{P}$ content of diet $\mathrm{B}$ was higher than that of diet $\mathrm{A}$ (Table 2). This was attributable to small amounts of these elements in the protein preparations (sodium caseinate, wheat gluten and soyabean protein isolate) and to unexpected differences between low-fat milk and yoghurt during diet B and full-fat milk and yoghurt during diet $\mathrm{A}$. However the increase (expressed as a percentage of intake during diet $\mathrm{A}$ ) in $\mathrm{N}, \mathrm{Ca}$ and $\mathrm{P}$ intake was the same for the young adults and the elderly. Energy expenditure, and therefore energy requirements and energy intake, generally decrease with advancing age because of decreases in BMR and physical activity. The lower BMR is strongly related to changes in body composition occurring with ageing. So the differences in energy intake and body composition described in the present study are well-described age-related differences. Therefore it is difficult to match elderly and young subjects by energy intake and by BMI. It is assumed that differences in energy balance (in terms of under- and overfeeding) between young and elderly subjects would have had more effect on the outcome of the study than differences in the absolute amount of (estimated) energy intake as described in the present study. Furthermore, there is no evidence that any measured response (urinary $\mathrm{Ca}$ excretion, faecal $\mathrm{Ca}$ excretion and $\mathrm{Ca}$ balance expressed as a percentage of $\mathrm{Ca}$ intake) was related to the estimated energy intake category. Since the energy intake of the young subjects was higher, the absolute amounts of $\mathrm{N}, \mathrm{Ca}$ and $\mathrm{P}$ consumed were also higher compared with the elderly.

\section{Calcium metabolism}

Data on $\mathrm{Ca}$ intake, $\mathrm{Ca}$ excretion and $\mathrm{Ca}$ balance are shown in Table 3. Since Ca intake was significantly higher during diet $\mathrm{B}$ (Table 2), $\mathrm{Ca}$ excretion in urine and faeces and $\mathrm{Ca}$ balance are expressed as a percentage of $\mathrm{Ca}$ intake. Since no differences were found between young and elderly subjects results are also given for the whole group. 
CALCIUM EXCRETION IN YOUNG AND OLD SUBJECTS
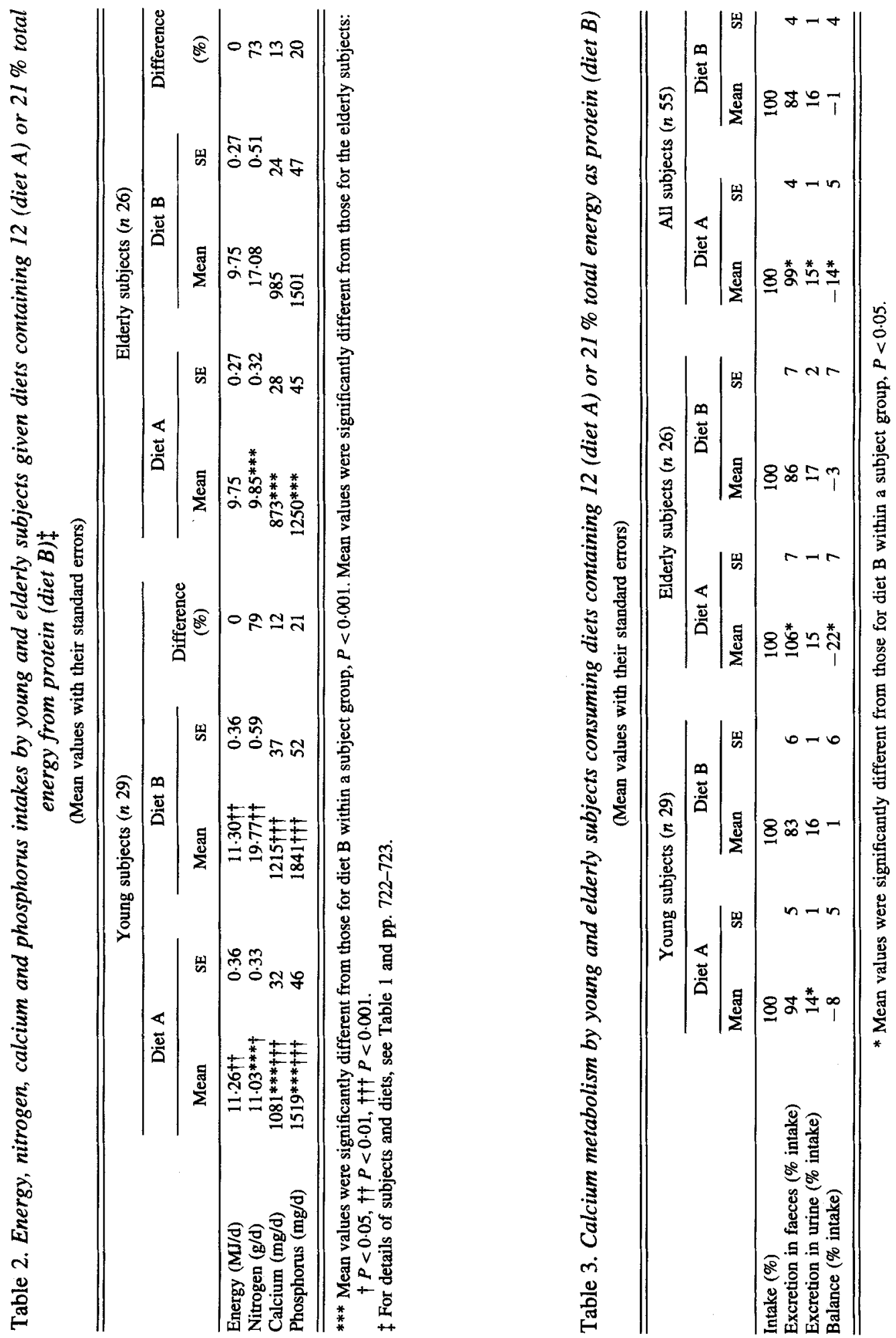
In the elderly, faecal $\mathrm{Ca}$ excretion, expressed as percentage of $\mathrm{Ca}$ intake, was significantly lower during consumption of the higher protein diet $(P=0.018)$. For the young adults there was a tendency for a lower faecal $\mathrm{Ca}$ excretion during the higher protein intake $(P=0 \cdot 09)$. Results for the whole group also showed a significant decrease in faecal $\mathrm{Ca}$ excretion $(P=0.0034)$. Consequently net apparent $\mathrm{Ca}$ absorption (calculated as $\mathrm{Ca}$ intake minus faecal $\mathrm{Ca}$ excretion) increased in the elderly and in the whole group during diet B (diet A: -6 (SEM 7) \%; diet B: 14 (SEM 7) \%; $P=0.018$ for the elderly; diet A: 1 (SEM 4) \%; diet B: 16 (SEM $4 \%$ ); $P=0.003$ for the whole group). In young adults there was a tendency for a higher apparent $\mathrm{Ca}$ absorption during the higher protein intake (diet $\mathrm{A}: 6$ (SEM 5) \%; diet B: 17 (SEM 6) \%; $P=0.09$ ).

In young adults and in the whole group, urinary $\mathrm{Ca}$ excretion, expressed as a percentage of $\mathrm{Ca}$ intake, was significantly higher during diet $\mathrm{B}$ (Table 3). The urinary $\mathrm{Ca}$ excretion of the elderly subjects also increased; however this was not statistically significant $(P=0 \cdot 24)$. Although it cannot be excluded that urine collection was incomplete, there was a high correlation and little variation between the creatinine excretion during diet $\mathrm{A}$ and that during diet $\mathrm{B}(P<0.0001 ; \mathrm{CV} 11 \%$ for both age groups).

In young adults $\mathrm{Ca}$ balance was not influenced by the amount of protein in the diet since there were no differences between $\mathrm{Ca}$ balance measured during diet $\mathrm{A}$ or diet $\mathrm{B}$. Data for the elderly and for the whole group showed that the $\mathrm{Ca}$ balance during $\operatorname{diet} \mathrm{A}$ was significantly more negative compared with $\mathrm{Ca}$ balance during diet $\mathrm{B}$, despite the higher urinary $\mathrm{Ca}$ excretion during diet $\mathrm{B}$ (Table 3).

\section{DISCUSSION}

There are many studies on effects of protein intake on the apparent absorption and urinary excretion of $\mathrm{Ca}$ and on $\mathrm{Ca}$ balance showing a negative effect of protein intake on Ca balance (Anand \& Linkswiler, 1974; Allen et al. 1979; Hegsted et al. 1981; Hegsted \& Linkswiler, 1981). However, no research has been done concerning the effect of age on the interaction between protein intake and $\mathrm{Ca}$ metabolism. Only one study has described the proteininduced hypercalciuria in older men and women, but no comparisons were made with young adults (Schuette et al. 1980). The aim of the present study was to investigate the effect of dietary protein on $\mathrm{Ca}$ excretion and $\mathrm{Ca}$ balance in young adults and in the elderly.

For each diet there were no significant differences in urinary $\mathrm{Ca}$ excretion between age groups, allowing comparison between the diets for the whole group. In the young subjects and the whole group, it was shown that a protein intake of $21 \%$ of total energy resulted in significantly higher urinary Ca excretion compared with a protein intake of $12 \%$ of total energy; urinary $\mathrm{Ca}$ excretion in the elderly seemed to increase also; however this was not statistically significant. For young adults this effect of protein intake on urinary $\mathrm{Ca}$ excretion has been described before (Johnson et al. 1970; Walker \& Linkswiler, 1972; Margen et al. 1974; Chu et al. 1975; Kim \& Linkswiler, 1979; Lutz \& Linkswiler, 1981; Zemel et al. 1981). The hypercalciuria at a high protein intake is mainly caused by a decrease in fractional tubular reabsorption of Ca (Allen et al. 1979; Kim \& Linkswiler, 1979; Schuette et al. 1980; Zemel et al. 1981) but there is also an increase in glomerular filtration rate (Chu et al. 1975; Allen et al. 1979; Kim \& Linkswiler, 1979; Schuette et al. 1980; Zemel et al. 1981). Spencer et al. (1978b, 1983) did not find an effect of (meat) protein intake on urinary $\mathrm{Ca}$ excretion. The authors suggested that commonly used complex proteins, which contain $\mathrm{P}$, do not cause Ca loss. As in the study of Schuette \& Linkswiler (1982), in the present study, urinary $\mathrm{Ca}$ excretion was increased while $\mathrm{P}$ intake was also increased. 
Walker \& Linkswiler (1972) and Anand \& Linkswiler (1974) described results for Ca excretion as measured during a $15 \mathrm{~d}$ dietary intervention period. Faeces were separated into $5 \mathrm{~d}$ composites and it was shown that faecal $\mathrm{Ca}$ did not vary significantly from any one $5 \mathrm{~d}$ period to another. Therefore the $3 \mathrm{~d}$ collection at the end of the 3-week intervention period was assumed to be representative for that period. Faecal $\mathrm{Ca}$ excretion, expressed as a percentage of $\mathrm{Ca}$ intake, was significantly lower during the higher protein intake (whole group $P=0.003$; elderly $P=0.018$; young adults $P=0.09$ ). Other authors have also reported a lower faecal Ca excretion when protein intake is increased (Walker \& Linkswiler, 1972; Chu et al. 1975) while others have not (Anand \& Linkswiler, 1974; Allen et al. 1979). As a consequence of the lower faecal Ca excretion, apparent absorption was significantly higher during diet $B$ for the elderly and for the whole group, and tended to be significantly higher for young adults $(P=0.09)$. These results indicate that the higher urinary $\mathrm{Ca}$ excretion was compensated by a higher intestinal apparent absorption of $\mathrm{Ca}$. The latter is probably attributable to the higher $\mathrm{P}$ intake; however, it is highly unlikely that the increase in $\mathrm{P}$ intake (250-300 $\mathrm{mg} / \mathrm{d}$ ) fully accounts for the differences in apparent $\mathrm{Ca}$ absorption as demonstrated by Spencer et al. (1978a). In that study no effect of high $\mathrm{P}$ intakes on intestinal $\mathrm{Ca}$ absorption were found. The results of our present study agree with those of studies in rats performed by Bell et al. (1975). They showed that an increase in the protein content of the diet from 10 to either 20 or $40 \%$ was associated with a shift in the route of endogenous $\mathrm{Ca}$ excretion from faeces to urine leading to an increase of apparent intestinal $\mathrm{Ca}$ absorption. Ca resorption from bone was not changed. Our results also agree with those of Schuette \& Linkswiler (1982) in human subjects. They found an increased urinary $\mathrm{Ca}$ excretion, $\mathrm{Ca}$ absorption and retention when protein intake was raised (together with $\mathrm{Ca}$ and $\mathrm{P}$ supplementation).

It could be argued that measuring faecal Ca excretion is subject to rather large errors, since subjects may fail to collect all the faeces, leading to overestimation of $\mathrm{Ca}$ absorption and to false positive $\mathrm{Ca}$ balances. To overcome this problem faecal $\mathrm{Ca}$ excretion was also expressed as $\mathrm{mg} \mathrm{Ca} / \mathrm{g}$ faeces. Expressed in this way no differences in faecal $\mathrm{Ca}$ excretion were seen (elderly: diet A 7.26 (SEM 0.55$) \mathrm{mg} / \mathrm{g}$; diet B 7.92 (SEM 0.63$) \mathrm{mg} / \mathrm{g}(P=0.15)$; young adults: diet A 9.12 (SEM 0.65 ) $\mathrm{mg} / \mathrm{g}$; diet B 10.06 (SEM 0.66$) \mathrm{mg} / \mathrm{g}(P=0.63)$ ), indicating indeed a lower fractional faecal $\mathrm{Ca}$ excretion on the high-protein diet.

$\mathrm{Ca}$ balance was calculated as intake minus excretion in urine and faeces. No corrections were made for $\mathrm{Ca}$ loss via sweat and dermal $\mathrm{Ca}$ losses since these losses are very small and are not affected by the level of protein and $\mathrm{Ca}$ intake (Chu et al. 1975). Again there were no statistically significant differences in Ca balance between the young and the elderly subjects. A higher protein intake (diet B) seems to have no effect on the Ca balance of young adults, despite the higher urinary $\mathrm{Ca}$ excretion. In the elderly and in the whole group, $\mathrm{Ca}$ balance was significantly less negative during diet $\mathrm{B}$. However as mentioned earlier, balance studies are susceptible to rather large errors since balance is calculated as the difference between two relatively large values, neither of which can be obtained with high accuracy. Although Ca balance was carried out as precisely as possible the results should be interpreted with care for several reasons: first, in the present study there were differences in $\mathrm{Ca}$ and $\mathrm{P}$ intake during both diets, making it difficult to draw definitive conclusions (as discussed earlier). Second, results were based on data collected over $3 \mathrm{~d}$ at the end of each dietary intervention period while subjects were under free-living conditions, and we cannot completely exclude the possibility that urine and faeces collections were incomplete. However, $24 \mathrm{~h}$ urinary creatinine excretion was in accordance with expected $24 \mathrm{~h}$ collections, and, because of the crossover design we used it is likely that any systematic error in collection occurred in both periods. Third, since $\mathrm{Na}$ intake is 
known to increase urinary Ca excretion (Short \& Flynn, 1990), any difference in Na intake between the two diet periods could have interfered with the effects on urinary Ca excretion. However, except for the sodium caseinate used to enrich milk products with protein, the specific foods we provided to create a difference in protein intake had similar contents of $\mathrm{Na}$. Thus $\mathrm{Na}$ intake increased only by $0.4 \mathrm{~g} / \mathrm{d}$ (for both young and elderly subjects) because of the sodium caseinate. Since we used a crossover design and since the $\mathrm{Na}$ contents of the products provided were almost equivalent it is highly unlikely that differences in $\mathrm{Na}$ intake could account for the calciuretic effect of protein.

Nevertheless it can be concluded that changing the protein intake from $12 \%$ to $21 \%$ of total energy had no negative effects on $\mathrm{Ca}$ balance in healthy young and elderly people. Others have reported a significant decrease in $\mathrm{Ca}$ balance as a result of a higher protein intake in young and middle-aged subjects (Anand \& Linkswiler, 1974; Allen et al. 1979; Hegsted et al. 1981; Hegsted \& Linkswiler, 1981) while others have not found an effect (Johnson et al. 1970; Spencer et al. 1978a, 1983; Schuette et al. 1980). Several factors have to be considered when comparing the results with those of other studies with respect to the effect of protein on Ca metabolism in humans, such as the type of protein (purified or complex proteins), the duration of the study (long term or short term), whether the studies were carried out in out-patient volunteers or under strictly controlled conditions, whether the $\mathrm{P}$ intake was higher, lower or the same during the intervention, and the age of the subjects. Since the study conditions of the different studies do differ it is hard to compare their results.

In conclusion it can be said that there were no differences between the two age groups with respect to the interaction between protein intake and $\mathrm{Ca}$ excretion, absorption and balance. Moreover urinary $\mathrm{Ca}$ excretion was increased in young and elderly subjects (whole group) when changing from 12 to $21 \%$ total energy as protein. This increase in $\mathrm{Ca}$ excretion in urine was compensated by an increased apparent $\mathrm{Ca}$ absorption (whole group). For the elderly this resulted in a less negative $\mathrm{Ca}$ balance during the higher protein intake whereas for the young adults there was no effect of protein intake on $\mathrm{Ca}$ balance. However for reasons mentioned earlier these data should be interpreted with care. It can be concluded that the present study confirms the hypercalciuretic effects of dietary protein but does not support the view that an increased protein intake has adverse effects on $\mathrm{Ca}$ balance, either in young or in elderly people.

\section{REFERENCES}

Allen, L. H., Oddoye, E. A. \& Margen, S. (1979). Protein-induced hypercalciuria: a longer term study. American Journal of Clinical Nutrition 32, 741-749.

Anand, C. R. \& Linkswiler, H. M. (1974). Effect of protein intake on calcium balance of young men given 500 $\mathrm{mg}$ calcium daily. Journal of Nutrition 104, 695-700.

Bell, A. A., Engelman, D. T., Sie, T.-L. \& Draper, H. H. (1975). Effect of high protein intake on calcium metabolism in the rat. Journal of Nutrition 105, 475-483.

Chu, J. Y. Margen, S. \& Costa, F. M. (1975). Studies in calcium metabolism. II. Effects of low calcium and variable protein intake on human calcium metabolism. American Journal of Clinical Nutrition 28, 1028-1035.

Grindler, E. M. \& King, J. D. (1972). Rapid colorimetric determination of calcium in biological fluids with methylthymol blue. American Journal of Clinical Pathology 58, 376-382.

Heany, R. P. (1986). Calcium intake, bone health and aging. In Nutrition, Aging and Health, pp. 165-186 [E. A. Young, editor]. New York: Alan R. Liss.

Hegsted, M. \& Linkswiler, H. M. (1981). Long-term effects of level of protein intake on calcium metabolism in young adult women. Journal of Nutrition 111, 244-251.

Hegsted, M., Schuette, S. A., Zemel, M. B. \& Linkswiler, H. M. (1981). Urinary calcium and calcium balance in young men as affected by level of protein and phosphorus intake. Journal of Nutrition 111, 553-562.

Henry, R. J., Cannon, D. C. \& Winkelman, J. W. (1974). Clinical Chemistry, Principles and Techniques 2 nd ed. New York: Harper and Row. 
Johnson, N. E., Alcantara, E. N. \& Linkswiler, H. (1970). Effect of level of protein intake on urinary and faecal calcium and calcium retention of young adult males. Journal of Nutrition 100, 1425-1430.

Kim, Y. \& Linkswiler, H. M. (1979). Effect of level of protein intake on calcium metabolism and parathyroid and renal function in adult human male. Journal of Nutrition 109, 1399-1404.

Lutz, J. \& Linkswiler, H. M. (1981). Calcium metabolism in post menopausal women consuming two levels of dietary protein. American Journal of Clinical Nutrition 34, 2178-2186.

Margen, S., Chu, J. Y., Kaufman, N. A. \& Calloway, D. H. (1974). Studies in calcium metabolism. I. The calciuretic effect of dietary protein. American Journal of Clinical Nutrition 27, 584-589.

Pannemans, D. L. E., Halliday, D. \& Westerterp, K. R. (1995). Whole-body protein turnover in elderly men and women: responses to two levels of protein intake. American Journal of Clinical Nutrition 61, 33-38.

Pannemans, D. L. E. \& Westerterp, K. R. (1993). Estimation of energy intake to feed subjects at energy balance as verified with doubly labelled water: a study in the elderly. European Journal of Clinical Nutrition 47, 490496.

Schuette, S. A. \& Linkswiler, H. M. (1982). Effects on Ca and P metabolism in humans by adding meat, meat plus milk, or purified protein plus $\mathrm{Ca}$ and $\mathrm{P}$ to a low protein diet. Journal of Nutrition 112, 338-349.

Schuette, S. A., Zemel, M. B. \& Linkswiler, H. M. (1980). Studies on the mechanism of protein induced hypercalciuria in older men and women. Journal of Nutrition 110, 305-315.

Short, C. \& Flynn, A. (1990). Sodium-calcium inter-relationships with specific reference to osteoporosis. Nutrition Research Reviews 3, 101-115.

Spencer, H., Kramer, L., DeBartolo, M., Norris, C. \& Osis, D. (1983). Further studies of the effect of a high protein diet as meat on calcium metabolism. American Journal of Clinical Nutrition 37, 924-929.

Spencer, N., Kramer, L. \& Osis, D. (1988). Do protein and phosphorus cause calcium loss? Journal of Nutrition 118, 657-660.

Spencer, H., Kramer, L., Osis, D. \& Norris, C. (1978a). Effect of phosphorus on the absorption of calcium balance in man. Journal of Nutrition 108, 447-457.

Spencer, H., Kramer, L., Osis, D. \& Norris, C. (1978b). Effect of high protein (meat) intake on calcium metabolism in man. American Journal of Clinical Nutrition 31, 2167-2180.

Walker, R. M. \& Linkswiler, H. M. (1972). Calcium retention in the adult human male as affected by protein intake. Journal of Nutrition 102, 1297-1302.

Zemel, M. B., Schuette, S. A., Hegsted, M. \& Linkswiler, H. M. (1981). Role of the sulphur-containing amino acids in protein-induced hypercalciuria in men. Journal of Nutrition 111, 545-552. 